\title{
Influence of crystalline titanium oxide layer smoothness on the performance of inverted organic bilayer solar cells
}

\author{
Etienne Berner, ${ }^{1, a)}$ Timo Jäger, ${ }^{2, a)}$ Thomas Lanz, ${ }^{3}$ Frank Nüesch, ${ }^{1,4}$ \\ Jean-Nicolas Tisserant, ${ }^{1}$ Gaetan Wicht, ${ }^{1}$ Hui Zhang, ${ }^{1}$ and Roland Hany ${ }^{1, b)}$ \\ ${ }^{1}$ Empa, Swiss Federal Institute for Materials Science and Technology, Laboratory for Functional Polymers, \\ CH-8600 Dübendorf, Switzerland \\ ${ }^{2}$ Empa, Swiss Federal Institute for Materials Science and Technology, Laboratory for Thin Films \\ and Photovoltaics, $\mathrm{CH}-8600$ Dübendorf, Switzerland \\ ${ }^{3}$ Institute of Computational Physics, ZHAW, Zürich University of Applied Sciences, CH-8401 Winterthur, \\ Switzerland \\ ${ }_{4}^{4}$ Institut des Matériaux, Ecole Polytechnique Fédéral de Lausanne, EPFL Station 12, CH-1015 Lausanne, \\ Switzerland
}

(Received 6 March 2013; accepted 21 April 2013; published online 10 May 2013)

\begin{abstract}
Due to the small exciton diffusion length in organic materials, the donor-acceptor heterointerface in simple bilayer solar cells must be placed in close proximity to the bottom electrode. This makes great demands on the planarity of the base layer, since a non-uniform topography can cause adverse shorting through overlying layers. We fabricated indium tin oxide (ITO)/titanium oxide $\left(\mathrm{TiO}_{\mathrm{x}}\right)$ /fullerene $\left(\mathrm{C}_{60}\right)$ /cyanine dye/molybdenum oxide $\left(\mathrm{MoO}_{3}\right)$ /silver $(\mathrm{Ag})$ solar cells with $\mathrm{TiO}_{\mathrm{x}}$ layers deposited via sputtering, coated from a nanoparticle suspension or prepared via a sol-gel process. A power conversion efficiency of $3.7 \%$ was measured when using a smooth sol-gel derived $\mathrm{TiO}_{\mathrm{x}}$ film. (C) 2013 AIP Publishing LLC. [http://dx.doi.org/10.1063/1.4804599]
\end{abstract}

Thin, dense films of $\mathrm{TiO}_{\mathrm{x}}$ have recently emerged as promising functional layers in hybrid inorganic-organic ${ }^{1}$ and purely organic solar cells (OSCs). $\mathrm{TiO}_{\mathrm{x}}$ layers have been used as optically transparent spacers to optimize the absorption within the active organic film and were a key component for the fabrication of solution-processed tandem OSCs. ${ }^{2,3}$ $\mathrm{TiO}_{\mathrm{x}}$ layers were used in the regular (substrate/hole selective contact/active organic layer $/ \mathrm{TiO}_{\mathrm{x}} /$ metal) and the inverted (substrate/ $\mathrm{TiO}_{\mathrm{x}} /$ active organic layer/hole selective contact/ metal) cell architecture. ${ }^{4-7}$ For both device geometries, $\mathrm{TiO}_{\mathrm{x}}$ is the electron-selective contact and thus forms the cathode. $\mathrm{TiO}_{\mathrm{x}}$ works as an effective barrier that prevents penetration of oxygen and water. In addition, $\mathrm{TiO}_{\mathrm{x}}$ acts as an active scavenging layer for removing oxygen and water ${ }^{8}$ enhancing the lifetime of OSCs considerably. 5,7

OSCs with highest power conversion efficiencies $(\eta)$ use organic films that are applied from a blend of an electronaccepting soluble fullerene derivative with a donor polymer $(\eta=9.2 \%$ (Ref. 9)) or small molecule $(\eta=7 \%$ (Ref. 10)) that form a bulk heterojunction (BHJ). Alternatively, the two organic components can be deposited one by one to create a planar bilayer heterojunction. The efficiency of bilayer OSCs is limited by the small geometrical junction area but is still in use for rapid screening purposes of molecules or when control over the nanoscale phase separation between the components in a blend film is challenging. ${ }^{11}$ In addition, a smooth and well-defined planar organic/organic interface is prerequisite to study fundamental opto-electronic processes at organic heterointerfaces. ${ }^{12}$

The active components in an OSC must intimately be in contact on a length scale of well below $\sim 50 \mathrm{~nm}$. This critical

\footnotetext{
${ }^{\text {a) }}$ E. Berner and T. Jäger contributed equally to this work

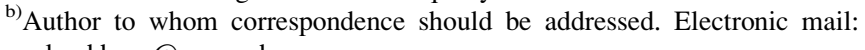
roland.hany@empa.ch.
}

distance corresponds to the exciton diffusion length $\left(\mathrm{L}_{\mathrm{ex}}\right)$ of organic semiconductors, and light absorption in regions further away from the heterointerface does not result in free charge carrier generation. ${ }^{13}$ The constraint of a small $\mathrm{L}_{\mathrm{ex}}$ results in an important difference between the required substrate smoothness a BHJ or a bilayer OSC is built on. In bilayer OSCs, the heterointerface is placed at a distance of only $\sim \mathrm{L}_{\mathrm{ex}}$ away from the bottom electrode, and a nonuniform topography of the substrate can cause shorting through other layers, resulting in low shunt resistance, high dark currents, and poor device performance. The substrate planarity is less critical for BHJ OSCs with typical active film thicknesses of 100-200 nm.

Cyanine dyes (Fig. 1(a)) are actually organic salts that are strongly incompatible with common apolar organic semiconducting materials. This makes the adjustment of a suitable BHJ morphology challenging. However, the very high light extinction coefficients of cyanines compensate for the exciton diffusion bottleneck, and thin $(\sim 30 \mathrm{~nm})$ dye films were used in OSCs produced in the regular and inverted bilayer configuration. ${ }^{14-16}$

Here, we investigated different $\mathrm{TiO}_{\mathrm{x}}$ films as electronselective base layers for the fabrication of inverted cyanine OSCs. $\mathrm{TiO}_{\mathrm{x}}$ layers were deposited onto glass/indium tin oxide (ITO) substrates (Thin Film Devices, resistivity $20 \Omega /$ sq, $150 \mathrm{~nm}$ thickness, root mean square, rms, roughness after cleaning $0.51 \mathrm{~nm}$ ). For films (samples A-C) deposited via reactive magnetron sputtering (ATC Orion, AJA International), the sputtering gas consisted of argon-oxygen mixtures $\left(\mathrm{O}_{2}\right.$ partial pressures between $26 \%$ and $89 \%$ ) at a total pressure of $4 \times 10^{-3}$ mbar, and a titanium metal disk (99.999\%) was used as the target. ${ }^{17}$ Alternatively, films (sample D) were spin coated from a $\mathrm{TiO}_{\mathrm{x}}$ nanoparticle $(\varnothing \sim 9 \mathrm{~nm})$ suspension (Solaronix, Ti-Nanoxide HT-L/SC). ${ }^{18}$ As a further method, crystalline $\mathrm{TiO}_{\mathrm{x}}$ films (sample E) were prepared via a sol-gel 
(a)

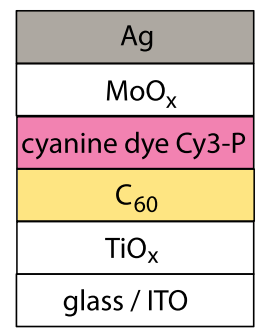

(b)

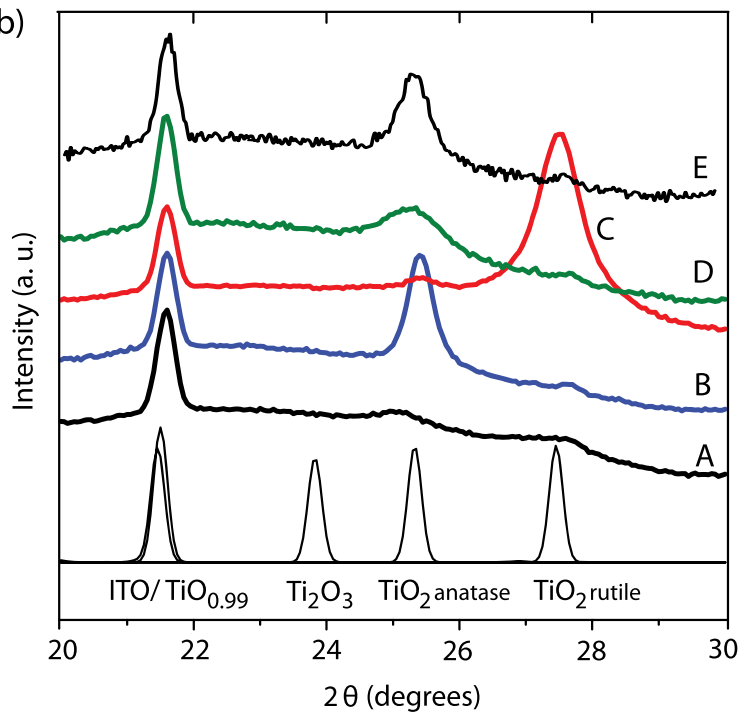

FIG. 1. (a) Schematic representation of the inverted bilayer solar cell. (b) $\mathrm{X}$-ray diffraction patterns of sputtered $\mathrm{TiO}_{\mathrm{x}}$ films (samples $\mathrm{A}$ and $\mathrm{B}$, thickness $\sim 40 \mathrm{~nm}, \mathrm{C} \sim 110 \mathrm{~nm}$ ), a nanoparticulate $\mathrm{TiO}_{\mathrm{x}}$ film (sample $\mathrm{D} \sim 45 \mathrm{~nm}$ ) and a sol-gel derived film (sample $\mathrm{E} \sim 50 \mathrm{~nm}$ ) prepared by spin coating on glass/ITO substrates.

process using titanium iso-propoxide as precursor. ${ }^{19}$ Amorphous $\mathrm{TiO}_{\mathrm{x}}$ films were spin coated onto the substrates using a $0.45 \mu \mathrm{m}$ filter. Films were then heated within $3 \mathrm{~h}$ to $460{ }^{\circ} \mathrm{C}$ in air, were kept for $2 \mathrm{~h}$ at that temperature, and were then cooled down to room temperature.

Crystallinity of the deposited films was investigated by X-ray diffraction (XRD, Kristalloflex D5000, Bruker). Therefore, the incident angle of the X-ray beam was fixed at an angle of $1^{\circ}(\theta)$, and the sensor was scanned between 20 and $302 \theta$ using a step increment of $0.052 \theta$. Nearly amorphous films (sample A, Fig. 1(b)) were deposited using rf sputtering $(13.4 \mathrm{MHz}, 200 \mathrm{~W})$ at a $\mathrm{O}_{2}$ partial pressure of $89 \%$ without heating the substrate. Phase-pure anatase films (sample B, Fig. 1(b)) were obtained via rf sputtering by increasing the substrate temperature to $200{ }^{\circ} \mathrm{C}$ and using an oxygen content of $57 \%$ in the sputtering gas. We note that films deposited on glass via rf sputtering were mostly amorphous, suggesting that ITO functions as a seed layer that promotes crystallization. Phase-pure rutile films on glass or ITO (sample C, Fig. 1(b)) could be produced by dc sputtering $\left(\mathrm{O}_{2}\right.$ content $26 \%$, substrate $\left.200{ }^{\circ} \mathrm{C}\right)$. Phase-pure anatase was present in the nanoparticle dispersion (sample D, Fig. 1(b)) and produced in the sol-gel derived film after sintering (sample E, Fig. 1(b)).

The film surface topography was characterized with AFM (Mobile S, NanoSurf). Sputtered phase-pure anatase films (Fig. 2(a)) were smooth ( $\mathrm{rms}$ roughness $=0.7 \mathrm{~nm}$, peak-to-valley height, $\mathrm{R}_{\mathrm{t}}=9 \mathrm{~nm}$ ), and a very similar planar
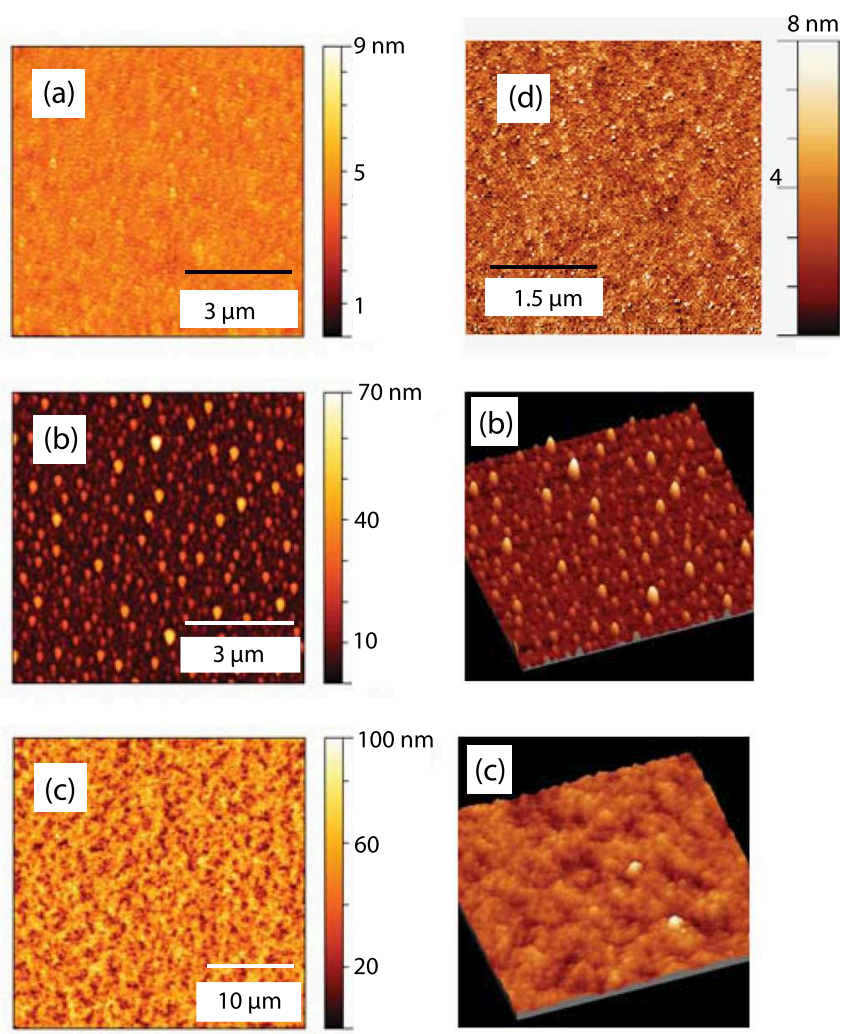

FIG. 2. AFM images of (a) a rf sputtered anatase $\mathrm{TiO}_{\mathrm{x}}$ film (sample B), (b) a dc sputtered rutile $\mathrm{TiO}_{\mathrm{x}}$ film (sample C), (c) a spin-coated nanoparticulate $\mathrm{TiO}_{\mathrm{x}}$ film (sample D), and (d) a sol-gel derived $\mathrm{TiO}_{\mathrm{x}}$ film (sample E).

topography was observed for amorphous films (rms roughness $=0.3 \mathrm{~nm}, \mathrm{R}_{\mathrm{t}}=7 \mathrm{~nm}$ ). Phase-pure rutile films (Fig. 2(b)) displayed a columnar texture with spikes protruding from the surface ( $\mathrm{rms}$ roughness $=7.3 \mathrm{~nm}, \mathrm{R}_{\mathrm{t}}=71 \mathrm{~nm}$ ). Also, the topography of the nanoparticulate $\mathrm{TiO}_{\mathrm{x}}$ film (Fig. 2(c)) was clearly non-planar $\left(\mathrm{rms}\right.$ roughness $\left.=11.5 \mathrm{~nm}, \mathrm{R}_{\mathrm{t}}=94 \mathrm{~nm}\right)$. However, the steepness of the individual spikes observed for the rutile surface was absent and the surface texture resembled a rolling hills morphology. Very planar surfaces were finally observed for the sol-gel derived films (rms roughness $0.9 \mathrm{~nm}, \mathrm{R}_{\mathrm{t}}=8 \mathrm{~nm}$, Fig. 2(d)).

Multilayer OSCs (Fig. 1(a)) were fabricated under $\mathrm{N}_{2}$ atmosphere using glass/ITO/TiO ${ }_{\mathrm{x}}$ substrates A-E. $\mathrm{C}_{60}$ $(40-80 \mathrm{~nm})$ and $\mathrm{MoO}_{3}(5-30 \mathrm{~nm})$ layers with different thicknesses were deposited by thermal evaporation $\left(<5 \times 10^{-6}\right.$ mbar $)$. Ag $(60 \mathrm{~nm})$ was evaporated through a shadow mask to define solar cells with active areas of $3.1 \mathrm{~mm}^{2}$ or $7.1 \mathrm{~mm}^{2}$. Cy3-P (FEW Chemicals) films $\left(16-20 \mathrm{~nm}, \lambda_{\max , \text { film }}=577 \mathrm{~nm}\right.$ (Ref. 14)) were spin coated onto $\mathrm{C}_{60}$ from 2,2,3,3-tetrafluoropropanol (TFP) solutions. The UV-vis absorption spectrum of a $\mathrm{C}_{60}$ film remained unchanged when repeatedly spin coated with pure solvent, confirming that the fullerene is completely insoluble in TFP.

Current-voltage (J-V) characteristics (Fig. 3) were measured under $\mathrm{N}_{2}$ using $100 \mathrm{~mW} \mathrm{~cm}^{-2}$ simulated AM1.5G solar irradiation on a calibrated solar simulator (Spectra-Nova). The performance characteristics were in accordance with the condition that a smooth and low-resistive $\mathrm{TiO}_{\mathrm{x}}$ base layer is required for the fabrication of efficient bilayer heterojunction solar cells. For the spiked rutile substrate (sample C), a high dark current with negligible rectification between forward 

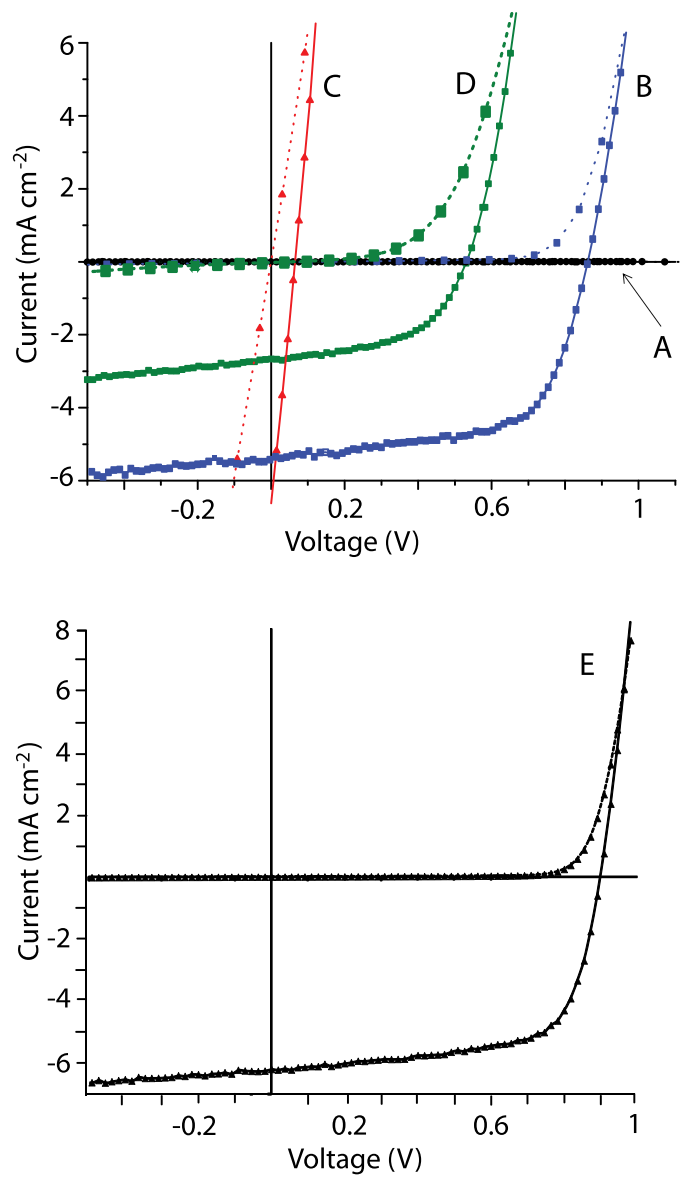

FIG. 3. J-V characteristics of glass/ITO/TiO $/ \mathrm{C}_{60} / \mathrm{Cy} 3-\mathrm{P}(16-20 \mathrm{~nm}) / \mathrm{MoO}_{3}$ $(30 \mathrm{~nm}) / \mathrm{Ag}(60 \mathrm{~nm})$ OSCs using different $\mathrm{TiO}_{\mathrm{x}}$ layers $(\mathrm{A}=$ sputtered, amorph; $\mathrm{B}=$ sputtered, anatase; $\mathrm{C}=$ sputtered, rutile; $\mathrm{D}=$ spin coated nanoparticle suspension, anatase; $\mathrm{E}=$ sol-gel process, anatase). Dottet lines indicate dark currents, solid lines are currents under light illumination $\left(100 \mathrm{~mW} \mathrm{~cm}^{-2}\right)$. The $\mathrm{C}_{60}$ layer thickness was $40 \mathrm{~nm}$ for samples A-C and E, and $80 \mathrm{~nm}$ for sample D.

and reverse bias was observed. This is the characteristic for short circuit conditions resulting in a low fill factor (FF) and open circuit voltage $\left(\mathrm{V}_{\mathrm{oc}}\right)$ for the device under illumination. Negligible performance was also observed for the smooth but amorphous $\mathrm{TiO}_{\mathrm{x}}$ layer (sample $\mathrm{A}$ ). In this case, the cathode was completely blocking $\left(\mathrm{V}_{\mathrm{oc}}=0.48 \mathrm{~V}, \mathrm{FF}=21.2 \%\right.$, short circuit current, $\mathrm{J}_{\mathrm{sc}}=1 \times 10^{-3} \mathrm{~mA} \mathrm{~cm}^{-2}$ ) consistent with the low conductivity of amorphous $\mathrm{TiO}_{\mathrm{x}}$ resulting in a device-limiting series resistance for film thicknesses above $\sim 10 \mathrm{~nm}^{5}$
OSCs performances increased for anatase $\mathrm{TiO}_{\mathrm{x}}$ layers $\mathrm{B}$, $D$, and $E$ with decreasing rms roughnesses and $R_{t}$ values (Fig. 3). To compensate for the pronounced waviness of the spin coated nanoparticulate $\mathrm{TiO}_{\mathrm{x}}$ base layer, the $\mathrm{C}_{60}$ layer thickness was increased to $80 \mathrm{~nm}$ for sample $\mathrm{D}$. This resulted in decent device performance with a low $\mathrm{J}_{\mathrm{sc}}\left(2.7 \mathrm{~mA} \mathrm{~cm}^{-2}\right)$, however (Table I). Incident photon-to-current conversion efficiency (IPCE) curves shown in Refs. 14 and 15 for $\mathrm{Cy} 3-\mathrm{P} / \mathrm{C}_{60}$ bilayer solar cells demonstrate that a considerable fraction of current is generated in the wavelength region where $C_{60}$ absorbs light. The reduced current for sample D can, therefore, probably be attributed to ineffective photoexcitation of $\mathrm{C}_{60}$ far away from the heterointerface where oxidative charge transfer and current generation occur $\left(\mathrm{L}_{\mathrm{ex}} \mathrm{C}_{60} \sim 40 \mathrm{~nm}\right.$ (Ref. 13)).

In addition, also $\mathrm{V}_{\mathrm{oc}}(0.52 \mathrm{~V})$ for sample $\mathrm{D}$ was lower than for $\mathrm{B}\left(\mathrm{V}_{\mathrm{oc}}=0.84 \mathrm{~V}\right)$ and $\mathrm{E}\left(\mathrm{V}_{\mathrm{oc}}=0.88 \mathrm{~V}\right)$. In recent work, $\mathrm{V}_{\mathrm{oc}}$ has been shown to be correlated to the redox energy levels of the active donor and acceptor materials. ${ }^{4}$ Specific reasons have been identified that limit $\mathrm{V}_{\mathrm{oc}}$, such as reverse saturation current, interfacial charge transfer states, or bimolecular charge recombination. ${ }^{20}$ For sample D, we consider that also shunt conduction contributes to the lowering of $\mathrm{V}_{\mathrm{oc}}$. The parallel resistance allows for leakage currents from sources such as pinholes. Considering the roughness of the spin-coated nanoparticulate $\mathrm{TiO}_{\mathrm{x}}$ layer, pinholes in the active $\mathrm{Cy} 3-\mathrm{P}$ and $\mathrm{C}_{60}$ layers can indeed be expected, leading to direct contact of the organic materials with both electrodes at the same time. These direct paths between anode and cathode act as a shunt resistance in parallel with the active part, resulting in a lowered $\mathrm{V}_{\mathrm{oc}}$ and eroding the device efficiency partly. Parallel resistance values $\left(R_{p}\right)$ in the dark were determined from the inverse of the slope $(\Delta \mathrm{J} / \Delta \mathrm{V})$ at short-circuit $(\mathrm{V}=0)$. The slope of $\mathrm{J}(\mathrm{V}=0)$ was obtained by a least squares fit of a linear curve to the experimental data in the linear regime, $[-0.2 \mathrm{~V},+0.2 \mathrm{~V}]$ in our case. $R_{p}$ was $2.6 \mathrm{k} \Omega \mathrm{cm}^{2}$ for sample $D$. For samples $B$ and $E$, dark current densities were significantly suppressed $\left(R_{p}=9\right.$ $\mathrm{k} \Omega \mathrm{cm}^{2}$ for $\mathrm{B}, 26.5 \mathrm{k} \Omega \mathrm{cm}^{2}$ for $\mathrm{E}$ ), consistent with reduced leakage current. Note that the spin-coated $\mathrm{TiO}_{\mathrm{x}}$ dispersion was used as a base layer in BHJ OSCs using a thickness of $200 \mathrm{~nm}$ for the organic film. ${ }^{18}$

Best solar cell performances were measured when using the sol-gel derived $\mathrm{TiO}_{\mathrm{x}}$ base layer (sample E, Table I). The highest efficiency was $\eta=3.7 \%$, with an average performance

TABLE I. Device performance/parameters from bilayer $\mathrm{C}_{60} / \mathrm{Cy} 3-\mathrm{P}$ solar cells.

\begin{tabular}{|c|c|c|c|c|c|}
\hline Device & $\mathrm{V}_{\mathrm{oc}}(\mathrm{V})$ & $\mathrm{J}_{\mathrm{sc}}\left(\mathrm{mA} \mathrm{cm}^{-2}\right)$ & $\mathrm{FF}(\%)$ & $\eta(\%)$ & Ref. \\
\hline $\mathrm{B}$, sputtered, ${ }^{\mathrm{a}}$ best & 0.84 & 5.4 & 63 & 2.9 & This work \\
\hline $\mathrm{B}$, average 4 cells & $0.83 \pm 0.1$ & $4.5 \pm 0.9$ & $62.2 \pm 1.1$ & $2.3 \pm 0.5$ & This work \\
\hline D, spin coated nanoparticle suspension & 0.52 & 2.7 & 53.6 & 0.8 & This work \\
\hline E, sol-gel process, best & 0.88 & 6.2 & 67.8 & 3.7 & This work \\
\hline $\mathrm{E}$, average 25 cells & $0.86 \pm 0.02$ & $6.6 \pm 0.8$ & $58.2 \pm 4.1$ & $3.3 \pm 0.4$ & This work \\
\hline ITO/ZnO/PCBM/Cy3-P/MoO $/ \mathrm{Ag}^{\mathrm{b}}$ & 1 & 1.5 & 43 & 0.6 & 16 \\
\hline ITO/ $/ \mathrm{MoO}_{3} / \mathrm{Cy} 3-\mathrm{P} / \mathrm{C}_{60}: \mathrm{BCP} / \mathrm{Ba}: \mathrm{Ag}^{\mathrm{b}}$ & 0.92 & 5.1 & 62 & 2.9 & 15 \\
\hline ITO/PANI:DBS/Cy3-P/C $60 / \mathrm{Alq}_{3} / \mathrm{Al}^{\mathrm{b}}$ & 0.72 & 6.9 & 61 & 3.0 & 14 \\
\hline
\end{tabular}

${ }^{\mathrm{a}}$ Different fabrication processes for the phase-pure anatase $\mathrm{TiO}_{\mathrm{x}}$ layers were used.

${ }^{\mathrm{b}} \mathrm{ZnO}=$ zinc oxide, $\mathrm{PCBM}=[6,6]$-phenyl- $\mathrm{C}_{61}$-butyric acid methyl ester, $\mathrm{BCP}=$ bathocuproine, $\mathrm{Ba}=$ barium, PANI:DBS $=$ polyaniline doped with dodecylbenzenesulfonic acid, $\mathrm{Alq}_{3}=$ tris-(8-hydroxyquinoline) aluminium. 
from 25 cells of $\eta=(3.3 \pm 0.4) \%$. These findings present a considerable improvement compared to reported efficiencies for bilayer fullerene/Cy3-P OSCs in the normal and inverted device geometry so far (Table I). ${ }^{14-16} \mathrm{We}$ also note that initial measurements of the stability of inverted cyanine solar cells showed promising results. Cells were stable when stored in the glove box for several months, and no sign of degradation was observed under illumination $\left(50 \mathrm{~mW} \mathrm{~cm}^{-2}\right)$ in nitrogen (for $24 \mathrm{~h}$ ) or ambient atmosphere (for $6 \mathrm{~h}$ ).

In conclusion, our results emphasize experimentally the importance of the planarity of the crystalline $\mathrm{TiO}_{\mathrm{x}}$ base layer onto which efficient inverted cyanine dye $/ \mathrm{C}_{60}$ bilayer OSCs could be fabricated. The promising results $(\eta=3.7 \%)$ using simple bilayer devices with small interfacial donor-acceptor area demonstrate the potential of cyanine dyes for OSC application. As an important advantage, cyanines are relatively cheap and are commercially available in large quantities. For cyanines with broader absorption spectra or by using mixtures of cyanines that absorb sunlight over the whole visible and into the near-infrared region, ${ }^{21}$ it is anticipated that efficiencies can be increased further. In practice, best OSCs were fabricated for $\mathrm{TiO}_{\mathrm{x}}$ films produced by a sol-gel process. $\mathrm{TiO}_{\mathrm{x}}$ sputtering of thin films for OSCs applications could be an interesting alternative. Sputtering is a large-area compatible coating technology. In addition, the sputter process temperature of $200^{\circ} \mathrm{C}$ to deposit phase-pure anatase $\mathrm{TiO}_{\mathrm{x}}$ layers would be compatible with polymer-based substrates that are interesting for the development of flexible OSCs. This is in contrast to the sol-gel route that required a high-temperature $\left(>450^{\circ} \mathrm{C}\right)$ annealing step to induce crystallization.

This work was supported by the Swiss Competence Center for Energy and Mobility, CCEM-CH, Dursol project.
${ }^{1}$ M. Helgesen, R. Søndergaard, and F. C. Krebs, J. Mater. Chem. 20, 36 (2010).

${ }^{2}$ J. Y. Kim, S. H. Kim, H.-H. Lee, K. Lee, W. Ma, X. Gong, and A. J. Heeger, Adv. Mater. 18, 572 (2006).

${ }^{3}$ J. Y. Kim, K. Lee, N. E. Coates, D. Moses, T.-Q. Nguyen, M. Dante, and A. J. Heeger, Science 317, 222 (2007).

${ }^{4}$ R. Steim, F. R. Kogler, and C. J. Brabec, J. Mater. Chem. 20, 2499 (2010).

${ }^{5}$ A. Hayakawa, O. Yoshikawa, T. Fujieda, K. Uehara, and S. Yoshikawa, Appl. Phys. Lett. 90, 163517 (2007).

${ }^{6}$ C. Waldauf, M. Morana, P. Denk, P. Schilinsky, K. Coakley, S. A. Choulis, and C. J. Brabec, Appl. Phys. Lett. 89, 233517 (2006).

${ }^{7}$ C.-Y. Li, T.-C. Wen, T.-H. Lee, T.-F. Guo, J.-C.-A. Huang, Y.-C. Lin, and Y.-J. Hsu, J. Mater. Chem. 19, 1643 (2009).

${ }^{8}$ S. Cho, K. Lee, and A. J. Heeger, Adv. Mater. 21, 1941 (2009).

${ }^{9}$ Z. He, C. Zhong, S. Su, M. Xu, H. Wu, and Y. Cao, Nature Photon. 6, 591 (2012).

${ }^{10}$ T. S. van der Poll, J. A. Love, T.-Q. Nguyen, and G. C. Bazan, Adv. Mater. 24, 3646 (2012).

${ }^{11}$ W. Kylberg, P. Sonar, J. Heier, J.-N. Tisserant, C. Müller, F. Nüesch, Z.-K. Chen, A. Dodabalapur, S. Yoon, and R. Hany, Energy Environ. Sci. 4, 3617 (2011).

${ }^{12}$ A. Tada, Y. Geng, Q. Wei, K. Hashimoto, and K. Tajima, Nature Mater. 10, 450 (2011).

${ }^{13}$ P. Peumans, A. Yakimov, and S. R. Forrest, J. Appl. Phys. 93, 3693 (2003).

${ }^{14}$ B. Fan, F. A. de Castro, B. T.-T. Chu, J. Heier, D. Opris, R. Hany, and F. Nüesch, J. Mater. Chem. 20, 2952 (2010).

${ }^{15}$ O. Malinkiewicz, T. Grancha, A. Molina-Ontoria, A. Soriano, H. Brine, and H. J. Bolink, Adv. Energy Mater. 3, 472 (2013).

${ }^{16} \mathrm{O}$. Malinkiewicz, M. Lenes, H. Brine, and H. J. Bolink, RSC Adv. 2, 3335 (2012).

${ }^{17}$ P. Zeman and S. Takabayashi, Surf. Coat. Technol. 153, 93 (2002).

${ }^{18}$ D.-S. Leem, A. Edwards, M. Faist, J. Nelson, D. D. C. Bradley, and J. C. de Mello, Adv. Mater. 23, 4371 (2011).

${ }^{19}$ M. J. Alam and D. C. Cameron, J. Sol-Gel Sci. Technol. 25, 137 (2002).

${ }^{20}$ A. Maurano, R. Hamilton, C. G. Shuttle, A. M. Ballantyne, J. Nelson, B. O'Regan, W. Zhang, I. McCulloch, H. Azimi, M. Morana, C. J. Brabec, and J. R. Durrant, Adv. Mater. 22, 4987 (2010).

${ }^{21}$ R. Hany, B. Fan, F. A. de Castro, J. Heier, W. Kylberg, and F. Nüesch, Prog. Photovoltaics 19, 851 (2011). 